УДК 347.191.1

DOI https://doi.org/10.32837/apdp.v0i92.3265

Ю. Я. Попко

\title{
ПРАВОВИЙ СТАТУС СІЛЬСЬКОГОСПОДАРСЬКИХ КООПЕРАТИВІВ ТА СІЛЬСЬКОГОСПОДАРСЬКИХ КООПЕРАТИВНИХ ОБ'ЄДНАНЬ ЗА ЗАКОНОДАВСТВОМ УКРАЇНИ
}

Постановка проблеми. Активний процес реформування приватних відносин в Україні відбувається на засадах гармонізації із принципами європейського приватного права. Окрім набрання чинності новим законодавством про сільськогосподарську кооперацію, відкриття ринку сільськогосподарських земель, актуалізації необхідності впорядкування відносин на ринку сільськогосподарського виробництва тощо, обговорюється проблематика удосконалення наявних організаційно-правових форм юридичних осіб та правових режимів майна, на яких вони діють.

Аналіз останніх досліджень і публікацій. Правовий статус сільськогосподарських кооперативів та сільськогосподарських кооперативних об'єднань був предметом дослідження багатьох учених, зокрема: В.А. Васильєвої, М.З. Вовк, А.В. Зеліско, В.М. Коссака, Н.С. Кузнєцової, І.М. Кучеренко, Р.В. Мавліханової, I.В. Спасибо-Фатєєвої, Т.М. Чурилової, В.С. Щербини, Ю.М. Юркевича та багатьох інших. Поряд з тим в умовах оновлення цивільного законодавства України науковий пошук у цій сфері залишається актуальним завданням.

Метою статті є здійснення детального теоретичного аналізу правового статусу сільськогосподарських кооперативів та сільськогосподарських кооперативних об’єднань за законодавством України та вироблення пропозицій з метою його удосконалення.

Виклад основного матеріалу. Розширення сфери суспільно-правового регулювання сільського господарства не означає, звісно, зникнення цивільно-правових відносин у цій галузі [1, с. 20]. Динамічність суспільного життя та докорінні зміни в економіці, політиці, соціальній сфері не можуть не відображатися на такій пов’язаній із ними сфері, як право [2, с. 24]. Тому слушно вказує Н.С. Кузнєцова, що цивільне законодавство, як відповідне правове поле, повинне бути предметом постійної уваги і постійних системних досліджень [3, с. 8].

Зазначаючи особливості досліджуваних юридичних осіб, доцільно зауважити, що, на думку А.В. Зеліско, комплексний аналіз Цивільного кодексу України (далі - ЦК України) та Закону України «Про кооперацію» свідчить про наявність у кооперативних відносинах членства тих специфічних ознак, що суттєво відрізняють їх від відносин участі в господарських товариствах. Ідеться, зокрема, про: особливості вступу до кооперативу; особливості здійснення прав та обов'язків членами кооперативу; обов'язкову особисту участь у діяльності кооперативу; механізми виключення зі складу членів кооперативу [4, с. 91].

Отже, згідно зі ст. 2 Закону України № 1087 від 10.07.2003 «Про кооперацію», кооператив - це юридична особа, утворена фізичними та/або юридичними особами, 
які добровільно об’єдналися на основі членства для ведення спільної господарської та іншої діяльності з метою задоволення своїх економічних, соціальних та інших потреб на засадах самоврядування [5]. У Цивільному кодексі України (далі ЦК України) згадка про сільськогосподарські кооперативи міститься, зокрема, у ст. ст. 84 та 86. Так, відповідно до ст. 84 ЦК України товариства, які здійснюють підприємницьку діяльність з метою одержання прибутку та наступного його розподілу між учасниками (підприємницькі товариства), можуть бути створені лише як господарські товариства (повне товариство, командитне товариство, товариство з обмеженою або додатковою відповідальністю, акціонерне товариство) або виробничі кооперативи чи сільськогосподарські кооперативи, сільськогосподарські кооперативні об'єднання, що діють з метою одержання прибутку [6]. Своєю чергою, згідно зі ст. 86 ЦК України, непідприємницькі товариства (сільськогосподарські кооперативи та сільськогосподарські кооперативні об'єднання, що діють без мети одержання прибутку, інші кооперативи, крім виробничих, об'єднання громадян тощо) та установи можуть поряд зі своєю основною діяльністю здійснювати підприємницьку діяльність, якщо інше не встановлено законом і якщо ця діяльність відповідає меті, для якої вони були створені, та сприяє її досягненню [6].

Відповідно до Закону України «Про сільськогосподарську кооперацію» № 819-IX від 21.07.2020 сільськогосподарський кооператив - це юридична особа, утворена фізичними та/або юридичними особами, які є виробниками сільськогосподарської продукції і добровільно об’єдналися на основі членства та на засадах самоврядування для провадження спільної господарської та іншої діяльності з метою задоволення економічних, соціальних та інших потреб. При цьому сільськогосподарське кооперативне об'єднання - це юридична особа, утворена сільськогосподарськими кооперативами, що добровільно об'єдналися на основі членства та на засадах самоврядування для провадження спільної господарської та іншої діяльності з метою задоволення економічних, соціальних та інших потреб [7]. Порівнюючи з європейським досвідом, варто зазначити, що, наприклад, серед наднаціональних об'єднань осіб у праві Європейського Союзу передбачені норми про європейське кооперативне товариство, а Регламент Ради (ЄС) № $1435 / 2003$ про статут європейського кооперативного товариства прийнятий 22 липня 2003 року [8]. Зокрема, кооперативами визнають переважно групи фізичних або юридичних осіб з особливими засадами функціонування, які відрізняють їх від інших економічних суб'єктів та охоплюють принципи демократичної структури та контролю, розподілення прибутку за фінансовий рік на справедливій основі [9, с. 351].

У вітчизняній юридичній літературі вказують, що демократичність контролю в кооперативах полягає перш за все в тому, що увесь процес управління - від приймання рішень до їх виконання - повністю контролюється членами кооперативу. Іншими словами, тим, хто користується послугами кооперативу, належить і право його контролю [10, с. 39]. При цьому слушним є твердження, що у разі недодержання особою для здійснення своїх прав вимог, які передбачені законодавством, суд може зобов'язати її припинити зловживання своїми правами, а також застосувати інші санкції, встановлені законом [11, с. 188]. 
Відповідно до ч. 1 ст. 6 Закону України «Про сільськогосподарську кооперацію» сільськогосподарський кооператив утворюється за рішенням установчих зборів його засновників. Найменування сільськогосподарського кооперативу має містити інформацію про його організаційно-правову форму - «сільськогосподарський кооператив» - та назву, що складається з власної назви та може містити інформацію про вид діяльності (виробничий, переробний, заготівельно-збутовий, постачальницький, сервісний, багатофункціональний тощо) сільськогосподарського кооперативу [7].

У законі також вказано, що сільськогосподарський кооператив може бути утворений шляхом реорганізації (злиття, поділу, виділу) іншого сільськогосподарського кооперативу [7]. 3 цього нормативного положення можемо виснувати, що порядок реорганізації сільськогосподарських кооперативів є відмінним від загальних правил реорганізації, встановлених у ст. 104 ЦК України для всіх видів юридичних осіб. Особливості полягають у тому, що: по-перше, законодавець не передбачив можливості створення сільськогосподарських кооперативів шляхом перетворення (що, наш погляд, не зовсім виправдано, адже такий кооператив міг би бути створений, для прикладу, шляхом перетворення фермерського господарства зі статусом юридичної особи); по-друге, законодавець означив виділ як спосіб реорганізації (що, на наш погляд, є абсолютно виправданим, адже виділ за своєю правовою природою є реорганізацією і такі положення доцільно внести також у ЦК України); по-третє, сільськогосподарський кооператив може бути шляхом перетворення лише припиненим, а сільськогосподарське кооперативне об'єднання, що діє без мети одержання прибутку, може бути створене у зв’язку зі зміною організаційно-правової форми (перетворення) непідприємницького сільськогосподарського кооперативу.

Як зауважує М.З. Вовк, для окремих видів господарських організацій (наприклад, акціонерних товариств, корпоративних фондів, фермерських господарств тощо) законодавством передбачені спеціальні умови їх створення та здійснення діяльності [12, с. 31]. 3 вище процитованих норм закону про сільськогосподарську кооперацію можемо також виснувати, що законодавством передбачено спеціальні умови створення сільськогосподарських кооперативів. Зокрема, до таких спеціальних умов необхідно відносити мінімальний чисельний склад (три члени, засновниками сільськогосподарського кооперативу можуть бути фізичні та (або) юридичні особи) та проведення установчих зборів.

Своєю чергою сільськогосподарські кооперативні об'єднання утворюються, провадять свою діяльність та припиняються на засадах і в порядку, передбаченому для сільськогосподарських кооперативів, з урахуванням такої специфіки: засновниками та членами сільськогосподарського кооперативного об'єднання можуть бути сільськогосподарські кооперативи, сільськогосподарські кооперативні об'єднання; сільськогосподарське кооперативне об'єднання утворюється за рішенням не менше двох засновників; найменування сільськогосподарського кооперативного об'єднання повинно містити інформацію про його організаційноправову форму «сільськогосподарське кооперативне об’єднання» та назву, що містить власну назву та може містити інформацію про вид діяльності коопера- 
тивного об'єднання [7]. Оскільки, на наш погляд, окремого урегулювання у законі потребує правовий режим майна, на якому можуть створюватися та провадити діяльність сільськогосподарські кооперативні об'єднання.

Рішення установчих зборів про утворення сільськогосподарського кооперативу оформлюється протоколом, яке підписує голова та секретар зборів. Особливою умовою проведення установчих зборів є те, що невід'ємною частиною протоколу установчих зборів сільськогосподарського кооперативу є реєстр осіб, які брали участь у таких зборах [7].

У Законі України «Про сільськогосподарську кооперацію» передбачено, що члени сільськогосподарського кооперативу відповідають за зобов'язаннями кооперативу в межах своєї частки, якщо інше не передбачено законом. Однак у законодавстві України встановлено різні правила щодо відповідальності членів кооперативів за їхніми зобов'язаннями, на що свого часу звертав увагу у своїх працях В.С. Щербина [13, с. 115]. При цьому Р.В. Мавліханова запропонувала вилучити із ЦК та Господарського кодексу України [14] положення, які передбачають субсидіарну відповідальність членів виробничого кооперативу за його зобов'язаннями, оскільки це суперечить Закону України «Про кооперацію» та фактично перетворює виробничий кооператив на товариство з додатковою відповідальністю [15, с. 3-4, 14]. На нашу думку, приписи Закону України «Про сільськогосподарську кооперацію» щодо відповідальності членів сільськогосподарського кооперативу за зобов'язаннями такого кооперативу можуть призводити у ситуації різного регулювання таких відносин різними нормативно-правовими актами рівної юридичної сили до неоднакового застосування. Тому видається, що доцільно запровадити однаковий механізм і в ЦК України, і в інших законодавчих актах, у тому числі у Законі України «Про сільськогосподарську кооперацію», відповідно до якого «члени кооперативу відповідають за зобов’язаннями кооперативу у межах своєї частки, якщо інше не передбачено установчим документом кооперативу» .

Досліджуючи правовий статус сільськогосподарських кооперативів та сільськогосподарських кооперативних об'єднань, вважаємо за можливе солідаризуватися з точкою зору I.M. Кучеренко, яка звертала увагу на доцільність укладення засновницького договору для всіх організаційно-правових форм юридичних осіб приватного права у ситуаціях, якщо це буде пов'язане із виникненням майнових прав на частку у їхніх засновників [16, с. 35,94$]$. Незважаючи на це, єдиним установчим документом сільськогосподарських кооперативів є їхній статут. Хоча у сільськогосподарських кооперативах законодавчо передбачено прийняття такого локального акта, як правила внутрішньогосподарської діяльності, останні вважаються внутрішнім нормативним документом відповідного кооперативу, який покликаний визначити особливі умови порядку реалізації приписів статуту сільськогосподарського кооперативу.

Джерелами формування майна сільськогосподарського кооперативу, сільськогосподарського кооперативного об'єднання є: вступні внески та вклади (у тому числі додаткові вклади); членські та цільові внески його членів; кошти, що надходять від провадження господарської діяльності кооперативу, кооперативного об'єднання; кошти, що надходять від провадження господарської діяльності створених 
кооперативом підприємств, установ, організацій, сільськогосподарських кооперативних об'єднань, учасником яких він є; кошти, отримані як державна фінансова підтримка згідно із Законом України «Про державну підтримку сільського господарства України»; грошові та майнові пожертвування, благодійні внески, гранти, гуманітарна допомога, безоплатна технічна допомога юридичних і фізичних осіб, у тому числі іноземних; інші надходження, не заборонені законодавством [7]. Щодо можливості внесення у статутний капітал майнових прав інтелектуальної власності, то, як зазначає В.А. Васильєва, наявна потреба ухвалення рішення з приводу допуску такої участі у статутному капіталі, що має бути відображено в установчих документах; позаяк учена також зауважує, що за умови формування статутного капіталу із залученням об’єктів патентного права, укладення або приєднання до установчого договору є необхідним для будь-яких юридичних осіб - корпорацій, незалежно від організаційно-правової форми [17, с. 10; 18, с. 15].

Здійснюючи аналіз кооперативів, що провадять діяльність у галузі сільського господарства, необхідно відзначити Закон України «Про державну підтримку сільського господарства України», який визначає основи державної політики у бюджетній, кредитній, ціновій, регуляторній та інших сферах державного управління щодо стимулювання виробництва сільськогосподарської продукції та розвитку аграрного ринку, а також забезпечення продовольчої безпеки населення [19]. При цьому, окрім іншого, цей Закон визначає поняття «сільськогосподарське підприємство» як юридичну особу, що є сільськогосподарським товаровиробником (втім, на нашу думку, у зв'язку із процесами рекодифікації та оновлення цивільного законодавства, зокрема того, що регулює статус учасників економічного обороту, термін «сільськогосподарське підприємство» у нормативних актах доцільно замінити на «сільськогосподарська юридична особа»).

Сільськогосподарський кооператив набуває статусу юридичної особи з моменту внесення відповідних відомостей до Єдиного державного реєстру юридичних осіб, фізичних осіб-підприємців та громадських формувань та здійснює свою діяльність до моменту припинення. Припинення сільськогосподарського кооперативу з правонаступництвом передбачає його злиття, приєднання, поділ чи перетворення (реорганізацію), а без правонаступництва - ліквідацію.

У разі ліквідації підприємницького сільськогосподарського кооперативу його майно та кошти, що залишилися після покриття вимог кредиторів, виплат дивідендів, зокрема, патронажних дивідендів, оплати праці, розрахунків із кооперативним об'єднанням, членом якого він є, розподіляються між членами кооперативу у порядку, визначеному його установчим документом. Натомість майно та кошти фонду розвитку підприємницького сільськогосподарського кооперативу не підлягають поділу між його членами і передаються за рішенням загальних зборів такого кооперативу іншому сільськогосподарському кооперативу, сільськогосподарському кооперативному об’єднанню (для зарахування до фонду розвитку такого кооперативу, кооперативного об’єднання), а в разі неприйняття такого рішення зараховуються відповідно до закону до державного або місцевого бюджету [7]. Свого часу В.С. Щербина, досліджуючи статус кооперативів та долю неподільного фонду у разі їх ліквідації, цілком обгрунтовано вказував, 
що подібна норма не узгоджується з приписами ст. 41 Конституції України, оскільки передбачає, по суті, протиправне (хоч і встановлене законом) позбавлення права приватної власності членів кооперативу, і у будь-якому разі таке передання коштів неподільного фонду іншій кооперативній організації суперечить законним інтересам власників [13, с. 115]. Такий підхід вважаємо обгрунтованим і щодо підприємницьких сільськогосподарських кооперативів, а тому норма ч. 4 ст. 33 Закону України «Про сільськогосподарську кооперацію» підлягає відповідній зміні. Натомість схожі правила, що стосуються непідприємницьких сільськогосподарських кооперативів і закріплені у ч. 5 ст. 33 Закону України «Про сільськогосподарську кооперацію», є виправданими та, на наш погляд, підлягають збереженню.

Висновки. Законодавство України про сільськогосподарську кооперацію загалом належним чином урегульовує питання правового статусу сільськогосподарських кооперативів та сільськогосподарських кооперативних об'єднань. Незважаючи на це, досі залишається актуальною необхідність удосконалення приписів Закону України «Про сільськогосподарську кооперацію» у частині регулювання порядку та способів реорганізації сільськогосподарських кооперативів, правового режиму майна, на якому створюються та діють сільськогосподарські кооперативні об’єднання, а також правових наслідків ліквідації сільськогосподарських кооперативів, створених з метою одержання прибутку.

\section{Jimepamypa}

1. Клюкин Б. Д. Правовое регулирование сельского хозяйства в США : автореф. дисс. ... д-ра юрид. наук. Москва, $1972.36 \mathrm{c.}$

2. Спасибо-Фатеева И. В. Наблюдения за тенденциями в гражданском праве. Проблеми иивільного права та процесу : матеріали наук.-практ. конф., присвяч. світлій пам'яті О. А. Пушкіна (Харків, 27 травня 2016 р.). МВС України, Харк. нац. ун-т внутр. справ, каф. цивільного права та процесу, каф. охорони інтелект. власності, цив.-прав. дисциплін. Всеукр. громад. орг. «Асоціація цивілістів України». Харків : ХНУВС, 2016. С. 24-28.

3. Кузнєцова Н. С. Завдання української цивілістики на зламі епох. Актуальні проблеми приватного права : матеріали міжнар. наук.-практ. конф., присвяч. 93-й річниці з дня народження д-ра юрид. наук, проф., чл.-кор. АН УРСР В.П. Маслова (Харків, 27 лютого 2015 р.). Національний університет «Юридична академія України імені Ярослава Мудрого», Національна академія правових наук України, Харківський обласний осередок Всеукраїнської громадської організації «Асоціація цивілістів України». Харків : Право, 2015. С. 7-11.

4. Зеліско А. В. Підприємницькі юридичні особи приватного права як суб'єкти цивільних правовідносин : дис... д-ра юрид. наук. Івано-Франківськ ; Київ, 2017. 571 с.

5. Про кооперацію : Закон України № 1087 від 10.07.2003. Офіиійний сайт Верховної Ради України. URL: https://zakon.rada.gov.ua/laws/show/1087-15/conv\#Text (дата звернення: 05.11.2021).

6. Цивільний кодекс України № 435-IV від 16.01.2003. Офіційний сайт Верховної Ради України. URL: https://zakon.rada.gov.ua/laws/show/435-15\#Text (дата звернення: 01.11.2021).

7. Про сільськогосподарську кооперацію : Закон України № 819-IX від 21.07.2020. Офіиійний сайт Верховної Ради України. URL: https://zakon.rada.gov.ua/laws/show/819-20/conv\#Text (дата звернення: 02.11.2021).

8. Регламент Ради (СС) № 1435/2003 про статут європейського кооперативного товариства (SCE) (CKT) від 22.07.2003. URL: https://ips.ligazakon.net/document/view/eu030058 (дата звернення: 03.11.2021).

9. Юркевич Ю. М. Договірні форми об'єднань фізичних та юридичних осіб у цивільному праві України : дис. ... д-ра юрид. наук. Львів, 2017. 437 с.

10. Чурилова Т. М. Правове регулювання діяльності сільськогосподарських обслуговуючих кооперативів : дис. ... канд. юрид. наук. Київ, 2011. 202 с. 
11. Правовий захист економічної конкуренції : навчальний посібник / В. М. Коссак, Ю. М. Юркевич. Львів : ЛНУ імені Івана Франка. 2013. 314 с.

12. Правові засади створення, діяльності та припинення юридичних осіб в Україні : навчальний посібник / Ю. М. Юркевич, У. Б. Андрусів, О. Б. Верба-Сидор та ін. ; за ред. Ю. М. Юркевича. Львів : ЛьвДУВС, 2019. 412 с.

13. Щербина В. С. Суб’єкти господарського права : монографія. Київ : Юрінком Інтер, 2008. 264 с.

14. Господарський кодекс України 436-IV від 16.01.2003. Офіиійний сайт Верховної Ради України. URL: https://zakon.rada.gov.ua/laws/show/436-15/conv\#Text (дата звернення: 01.11.2021).

15. Мавліханова Р. В. Виробничі кооперативи як суб'єкти цивільного права : автореф. дис. ... канд. юрид. наук. Харків, 2005. 18 с.

16. Кучеренко I. М. Організаційно-правові форми юридичних осіб приватного права : монографія. Київ : Ін-т держави і права ім. В. М. Корецького НАН України, 2004. 328 с.

17. Васильєва В. А. Промислова власність і корпоративна власність: конкуренція норм. Корпоративне право України та інших європейських країн: порівняльно-правова характеристика : збірник наукових праць за матеріалами Міжнародної науково-практичної конференції (м. Івано-Франківськ, $26-27$ вересня 2014 р.). С. $9-17$.

18. Васильєва В. А. Промислова власність і корпоративна власність: конкуренція норм. Право і суспільство. 2015. Вип. 1. С. 14-21.

19. Продержавнупідтримку сільськогогосподарства України:ЗаконУкраїни№1877від 24.06.2004. Офіиійний сайт Верховної Ради України. URL: https://zakon.rada.gov.ua/laws/show/1877-15/ ed20220101/conv\#Text (дата звернення: 03.11.2021).

\section{Анотація}

Попко Ю. Я. Правовий статус сільськогосподарських кооперативів та сільськогосподарських кооперативних об’єднань за законодавством Украӥни. - Стаття.

Активний процес реформування приватних відносин в Україні відбувається на засадах гармонізації із принципами європейського приватного права. Окрім набрання чинності новим законодавством про сільськогосподарську кооперацію, відкриття ринку сільськогосподарських земель, актуалізації необхідності впорядкування відносин на ринку сільськогосподарського виробництва тощо, обговорюється проблематика удосконалення наявних організаційно-правових форм юридичних осіб та правових режимів майна, на яких вони діють.

Сільськогосподарський кооператив - це юридична особа, утворена фізичними та/або юридичними особами, які є виробниками сільськогосподарської продукції і добровільно об'єдналися на основі членства та на засадах самоврядування для провадження спільної господарської та іншої діяльності з метою задоволення економічних, соціальних та інших потреб. Сільськогосподарський кооператив набуває статусу юридичної особи з моменту внесення відповідних відомостей до Єдиного державного реєстру юридичних осіб, фізичних осіб-підприємців та громадських формувань та здійснює свою діяльність до моменту припинення. Сільськогосподарське кооперативне об'єднання - це юридична особа, утворена сільськогосподарськими кооперативами, що добровільно об'єдналися на основі членства та на засадах самоврядування для провадження спільної господарської та іншої діяльності з метою задоволення економічних, соціальних та інших потреб.

Законодавство України про сільськогосподарську кооперацію загалом належним чином урегульовує питання правового статусу сільськогосподарських кооперативів та сільськогосподарських кооперативних об'єднань. Незважаючи на це, досі залишається актуальною необхідність удосконалення приписів Закону України «Про сільськогосподарську кооперацію» у частині регулювання порядку та способів реорганізації сільськогосподарських кооперативів, правового режиму майна, на якому створюються та діють сільськогосподарські кооперативні об’єднання, а також правових наслідків ліквідації сільськогосподарських кооперативів, створених з метою одержання прибутку.

Ключові слова: кооператив, сільськогосподарський кооператив, сільськогосподарське кооперативне об'єднання, статут, юридична особа. 


\section{Summary}

Popko Yu. Ya. Legal status of agricultural cooperatives and agricultural cooperative assossiations under the legislation of Ukraine. - Article.

The active process of reforming private relations in Ukraine is based on harmonization with the principles of European private law. In addition to the entry into force of new legislation on agricultural cooperation, opening the market of agricultural land, updating the need to regulate relations in the market of agricultural production, etc., it is discussed the improvement of existing legal forms of legal entities and legal regimes on which they operate.

An agricultural cooperative is a legal entity formed by individuals and/or legal entities that are producers of agricultural products and voluntarily united on the basis of membership and on the basis of self-government to conduct joint economic and other activities to achive economic, social and other needs. An agricultural cooperative acquires the status of a legal entity from the moment of entering the relevant information into the Unified State Register of Legal Entities, Individual Entrepreneurs and Public Associations and carries out its activities until the moment of termination. An agricultural cooperative association is a legal entity formed by agricultural cooperatives that have voluntarily merged on the basis of membership and on the basis of self-government to conduct joint economic and other activities to achive economic, social and other needs.

The legislation of Ukraine on agricultural cooperation in general properly regulates the issue of the legal status of agricultural cooperatives and agricultural cooperative assossiations. Despite this, there is the need to improve the provisions of the Law of Ukraine "On Agricultural Cooperation" in terms of regulating the procedure and methods of reorganization of agricultural cooperatives, the legal regime of property on which agricultural cooperative assossiations are established and operate, as well as the legal consequences of liquidation of agricultural cooperatives, created for profit.

Key words: cooperative, agricultural cooperative, agricultural cooperative association, charter, legal entity. 